\title{
Ecological Management: a Research Agenda Guest Editorial
}

\section{Vincent Blok ${ }^{1}$}

Published online: 12 February 2021

(C) The Author(s), under exclusive licence to Springer Nature Switzerland AG 2021, corrected publication 2021

\begin{abstract}
This editorial sketches the relevancy and urgency of philosophical reflection on issues in ecological management. It subsequently provides a research agenda for future research on ecological management in the field of philosophy of management. Finally, it introduces the three articles that are part of this special issue.
\end{abstract}

Keywords Philosophy of management · Ecological management · Circular economy $\cdot$ Research agenda

As it becomes increasingly clear nowadays that humanity is using more natural resources than the earth can provide, and that we need two or more planets to support our modern way of living in the future (WWF 2012), many scholars and policy makers call for the transformation to a circular economy in order to ensure the sustainability of Earth's life support system (Kolbert 2011). In this view, the sustainability of the life support systems of planet Earth is threatened by environmental problems like global warming, and business managers are seen as change agents in this transformation to the circular economy.

At the same time, it is especially business management which can be associated with the destruction of the eco-systems of planet earth; it seems to be the case that since the start of the Industrial Revolution, our species alone has used management to make the sort of seismic changes to the biosphere previously reserved only to volcanic activity. It is in this respect, that business is often seen as part of the problem, rather than part of the solution. It is precisely our practice of management in business, that has been the architect of the remarkable economic success of the past 300 years, that has plunged the planet at the same time into ecological crisis.

If the current situation demands the transformation to the circular economy in order to ensure the sustainability of Earth's life support systems on the one hand, while precisely business management can be seen as one of the root causes of the ecological crisis we face today, the question emerges what exactly is the nature of management, why it contributes to environmental problems like global warming, and what alternative ways of conceptualising management

Vincent Blok

vincent.blok@wur.nl

1 Philosophy Group, Wageningen University (The Netherlands), Wageningen, Netherlands 
are available that contribute to the stewardship of planet earth? What does the transformation to the circular economy require from our management practices? What is needed is that we move beyond current conceptualizations of corporate sustainability and philosophically reflect on the role of ecological management in the circular economy.

While the normative and social dimension of the transition toward a circular economy started to receive attention in the literature (Blok 2021; Inigo and Blok 2019), as well as the philosophical underpinning of the circular economy (De Angelis and Lanulardo 2020) and the biobased economy (Zwier et al. 2015; Veraart and Blok 2020), the nature of management and how it can inform circular economy received less attention. In this respect, it is significant that 'management' is not necessarily a term that characterizes human behaviour, but can be associated with processes in nature, ranging from self-organisation and cooperation within animal groups and eco-systems to the way the life support systems of planet Earth maintain themselves. Although business management implies conscious decision making and control - which can be questioned to be at stake in natural eco-systems - natural management and control may inspire organisational management. Mark Dibben, when an executive editor of this journal, once asserted that we are not the only species that engages in management. The argument was that most creatures engage in managing their environment, by making shelter / having special places where they rest and reproduce, finding and storing food and even creating paths that run to and from the food and the shelter. Thus, insects, spiders, birds, fish, reptiles, and mammals all practice management to some degree. Management is therefore better understood as inherent in Nature, a Universal aspect of Purposeful Life. That is to say, some aspects of the behaviour of social creatures - lions, ants etc. — display at least parallels with human organised management. These forms of ecological management of natural systems may yet inspire a human type of management of organisations that is not only better able to grow and learn from nature, instead of depleting it - in this respect, ecological management is inspired by the emerging field of ecological economy (Daly and Farley 2004). It also tries to reconceptualise human management and control practices based on ecological management practices in order to contribute to the transformation to the circular economy.

A call for papers was published for a special track under the annual Philosophy of management conference which was held in Greenwich 2018. ${ }^{1}$ It raised the following philosophical questions to be addressed:

1. What is the role of organisational management and the logic of economic growth in the depletion of the natural resources of planet earth?

2. To what extent is organisational management dominated by a hegemony of engineering and control of nature, and what explains this?

3. To what extent can ecological management of natural systems inspire a more comprehensive, relational and integral way of management in business practices, for instance sustainable entrepreneurship?

4. What forms of nature-based or ecological management - biomimicry, eco-mimesis (Blok and Gremmen 2016) can be found in the natural environment and can inspire ecological management?

5. What are the advantages and disadvantages of ecological management in the natural world and of ecological management in business organisations?

\footnotetext{
${ }^{1}$ The call was originally developed in collaboration with Marc Dibben, who unfortunately had to leave the problem due to health issues. I would like to take this opportunity to thank him for the collaboration, his friendship and inspiration.
} 
6. What are the antecedents of ecological management in business organisations (values, world-view, experience of environmental distress etc.)?

7. What are the consequences of eco-logical management for eco-nomic institutions operating in the circular economy?

8. What is the role of ecological management for acknowledging and addressing the embeddedness of the socio-economic system within the natural system beyond its function as resource and waste sink? Can ecological management better represent the intrinsic value of nature other than its functions in the economic system?

9. How are the biosphere and the economic sphere related to each other in the biobased or circular economy?

This special issue is a collection of some of the selected words that the track contained and a first effort to address part of the research agenda. All contributions provide an answer to the first question of the research agenda. They see the mainstream economic paradigm and the main explanatory factor for the environmental disruption we face today. Taking this critical stance as a starting point, all contributions subsequently propose an alternative approach which is inspired by concepts like cradle to cradle (Kopnina 2021), holism (Heikkurinen et al. 2021) and ecological economics (Temesgen et al. 2021). In this, all articles contribute to the seventh question of our research question, although from different directions.

In the first contribution, Helen Kopnina discusses the concepts of Cradle to Cradle and Circular Economy in relation to sustainable production. It first philosophically reflect on economic growth and the risk of subversion of managerial practice to business as usual. It subsequently asks what can be expected from ecological management in circular production, based on a case study of master students involved in an education program on sustainable production and consumption (Kopnina 2021).

In the second contribution, Pasi Heikkurinen and colleagues discuss the philosophy of management as it is associated with the paradigm of productivism. It argues against productivism as it is inconsistent with the ideal of a circular economy, and proposes a philosophy of management that is complemented with a more holistic and processual view of organizations (Heikkurinen et al. 2021).

In the third contribution, Temesgen and colleagues discuss how the mainstream economics paradigm contributes to global warming and requires a new ontological, epistemological and axiological paradigm to address the environmental, economic and social problems we face today. To this end, they consult the conceptuality provided by ecological economics that can inform a genuine concept of circular economy (Temesgen et al. 2021).

With this special issue, our intention was to initiate more philosophical reflection in this particular emerging field in the philosophy of management domain. At the same time, the collection of articles clearly shows that the philosophical reflection on this topic just started. In addition to the proposed research agenda, the various contributions lay out the ground for further philosophical reflections and discussions in the future.

\section{References}

Blok, V. 2021. The normative and social dimensions of the transition toward a responsible circular biobased economy. In Representations and Rights of the Environment, ed. P. Stoett and S. Lamalle. Cambridge: Cambridge University press (forthcoming). 
Blok, V., and B. Gremmen. 2016. Ecological innovation: Biomimicry as a new way of thinking and acting ecologically. Journal of Agricultural and Environmental Ethics 29: 203-217.

Daly, H.E., and J. Farley. 2004. Ecological economics: Principles and practice. Washington DC: Island Press.

De Angelis, R., and G. Ianulardo. 2020. Circular economy as fictional expectation to overcome societal addictions. Where do we stand? Philosophy of Management 19: 133-153.

Heikkurinen, P., T. Ruuska, and A. Kuokkanen. 2021. Leaving Productivism behind: Towards a holistic and Processual philosophy of ecological management. Philosophy of Management. https://doi.org/10.1007/ s40926-019-00109-w.

Inigo, E., and V. Blok. 2019. Strengthening the socio-ethical foundations of the circular economy: Lessons from responsible research and innovation. Journal of Cleaner Production 33: 280-291.

Kolbert, E. 2011. Enter the Anthropocene-Age of man. National Geographic (March 2011).

Kopnina, H. 2021. Towards ecological Management: Identifying Barriers and Opportunities in Transition from Linear to Circular Economy. Philosophy of Management. https://doi.org/10.1007/s40926-019-00108-x.

Temesgen, A., V. Storsletten, and O. Jakobsen. 2021. Circular economy-Reducing symptoms or radical change? Philosophy of Management. https://doi.org/10.1007/s40926-019-00112-1.

Veraart, R., and V. Blok. 2020. Towards a philosophy of a bio-based economy: A Levinassian perspective on the relations between economic and ecology systems. Environmental Values. https://doi.org/10.3197/ $096327120 X 15916910310626$.

WWF. 2012. Living planet report 2012. Gland: WWF.

Zwier, J., V. Blok, and P. Lemmens. 2015. The ideal of a zero-waste Humanity: Philosophical Reflections on the Demand for a Bio-Based Economy. Journal of Agricultural and Environmental Ethics. https://doi.org/10. 1007/s10806-015-9538-y.

Publisher's Note Springer Nature remains neutral with regard to jurisdictional claims in published maps and institutional affiliations.

Vincent Blok is associate professor in Philosophy and Ethics of Technology and Innovation at the Philosophy Group, Wageningen University (The Netherlands). Blok's research group is specialized in Business Ethics, Philosophy of Technology and Responsible Innovation. His books include Ernst Jünger's Philosophy of Technology. Heidegger and the Poetics of the Anthropocene (Routledge, 2017) and Heidegger's Concept of philosophical Method (Routledge, 2020). Blok published over hundred articles in high ranked philosophy journals like Environmental Values, Business Ethics Quarterly, Synthese and Philosophy \& Technology, and in multi-disciplinary journals like Science, Journal of Cleaner Production, Public understanding of Science and Journal of Responsible Innovation. See www.vincentblok.nl for more information about his current research. 